Generálmajor Ing. Miroslav Žižka, Ing. Pavel Zůna, MSS., Ph.D.

Př́prava veřejných strategií

v podmínkách rezortu obrany:

Koncepce výstavby armády

Vojenské rozhledy, 2013, roč. 22 (54), č. 3, s. 15-26, ISSN 1210-3292

\title{
Public Strategies Preparation in Defence: Forces Development Concept
}

\section{Abstrakt:}

Slovo koncepce je dnes jedním z nejužívanějších pojmů v dlouhodobém a střednědobém ř́zení rezortu obrany. Tvorba koncepcí se prolíná celou řadou rezortních normativi̊ a je náplní působností téměr všech organizačních celků Ministerstva obrany a Generálního štábu Armády České republiky. Pojem tvorba koncepcí je svým způsobem zaklínadlem, které použiváme vždy, pokud jde o prípravu dlouhodobých a střednědobých strategických rozvojových dokumentů. Článek obsahuje analýzu zákonných východisek upravujicích tvorbu strategických dokumentů v podmínkách rezortu obrany a dále analyzuje implikace Metodiky střednědobých koncepcí a Metodiky př́pravy veřejných strategií na tvorbu rezortních strategických dokumenti̊.

\section{Abstract:}

Today, the word Concept is one of the most used terms in the framework of long and medium term of defence management. Concepts development as a process is mentioned in significant number of departmental regulations and descriptions of activities of organizational bodies of the Ministry of Defence and General Staff. Concepts development and Experimentation is a kind of incantation used when we speak about the development of long and medium term strategic documents. This article comprises the analysis of the legal regulations concerning the development of strategic documents. It analyses the implications of the governmental Methodology of mid-term concepts and Methodology of preparation of public strategies for departmental strategic documents.

Klíčová slova:

Koncepce, strategie, výstavba armády, dlouhodobé a střednědobé řízení rezortu obrany, rezortní normativ, organizační celek, tvorba koncepcí, metodika střednědobých koncepcí, tvorba rezortních strategických dokumentů.

Key words:

Concept, strategy, armed forces development, long and medium term defence management, departmental regulation, organizational body, concepts development, methodology of mid-term concepts, development of departmental strategic documents. 
Motto:

„Válka je př́liš závažný podnik pro osud národa, aby byl ponechán na rozhodnutí pouhých stratégů. Potřebujeme širší horizont, velké strategie', která pojme mírový stav předcházející každou válku. "

B. H. Liddell Hart (Thoughts on War, 1944)

Slovo koncepce je dnes jedním z nejužívanějších pojmů v dlouhodobém a střednědobém řízení rezortu obrany. Tvorba koncepcí se prolíná celou řadou rezortních normativů a je náplní působnosti téměř všech organizačních celků Ministerstva obrany a Generálního štábu Armády České republiky. Pojem tvorba koncepcí je svým způsobem zaklínadlem, které používáme vždy, pokud jde o přípravu dlouhodobých a střednědobých strategických rozvojových dokumentů.

Např́klad Dlouhodobá vize rezortu obrany (2008) hovoří o „dalších navazujících koncepčních dokumentech“. Bílá kniha o obraně (2011) si dala za cíl vymezit „koncepční principy a konkrétní cíle" pro rozvoj ozbrojených sil. V tomto dokumentu se slovo koncepce v různých tvarech nachází více jak čtyřicetkrát. Obranná strategie České republiky (2012) hovoří o „koncepční př́ípravě na mobilizaci“. Směrnice pro plánování činnosti a rozvoje rezortu obrany na roky 2013-2017 hovoří o „koncepčním a metodickém řízení“ jednotlivých oblastí činností a rozvoje. Patrně nejznámějším dokumentem, který má ve svém názvu slovo koncepce, je Koncepce rozvoje Armády České republiky (2009). Tehdejším záměrem ministra obrany nebylo předložit tuto koncepci vládě ke schválení, a proto nesl dokument v názvu „rozvoje“ a ne „výstavby“.

Termínu tvorba strategických dokumentů, včetně koncepcí, je v rámci rezortu obrany chybně používáno, čehož důsledkem je konkrétní pojmenování strategických dokumentů, kterému neodpovídá jejich obsah.

Doposud se zpracování koncepcí v rezortu ř́dilo Metodikou střednědobých koncepcí, kterou schválila vláda svým usnesením 3. ledna 2001. [1] V letech 2010 až 2012 byl, v gesci vlády České republiky, realizován projekt Metodika př́pravy veřejných strategii a výsledek byl prezentován na internetových stránkách Portálu veřejných strategií. [2] I když tento dokument nebyl (prozatím) schválen vládou jako metodika z roku 2001, tak se pomalu stává normou pro veřejnou správu.

Aniž by to bylo všeobecně známo, tak koncepční strategické dokumenty v působnosti rezortu obrany jsou upraveny zákony České republiky.

V tomto článku je uvedena analýza zákonných východisek upravujících tvorbu koncepcí, můžeme říci veřejných strategií, v podmínkách rezortu obrany, a dále rozklad implikací Metodiky střednědobých koncepcí a Metodiky prípravy veřejných strategií na tvorbu rezortních strategických dokumentů.

\section{Zákonná východiska tvorby koncepcí v podmínkách rezortu obrany}

Koncepční strategické dokumenty veřejné správy, včetně rezortu obrany, upravují obecně platné zákony a zákony platné pro př́slušný rezort. Z tohoto pohledu je nejvýše postaven zákon č. 2/1969 Sb. o zřízení ministerstev a jiných ústředních orgánů státní správy České republiky, ve znění pozdějších úprav. [3] Tento zákon, v § 22, říká, 
že ministerstva zkoumaji společenskou problematiku v okruhu své působnosti, analyzují dosahované výsledky a činí opatření k řěsení aktuálních otázek. Zpracovávají koncepce rozvoje svěřených odvětví a řě̌ení stěžejních otázek, které předkládají vládě České republiky.

Za svěřené odvětví lze podle zákona 222/1999 Sb. o zajišt'ování obrany České republiky, [4] §2, písm. (1), považovat zajištění obrany státu. Za řešené stěžejní otázky, podle stejného zákona, lze považovat:

a) výstavbu účinného systému obrany,

b) prrípravu odpovídacích sil a prostředků,

c) použití odpovídajících sil a prostředků a

d) účast v kolektivním obranném systému.

Podle platných legislativních norem rezort obrany předkládá a vláda schvaluje následující (seřazeno dle čísla příslušného zákona):

a) Koncepci operační přípravy národního území (zákon č. 2/1969 Sb., $\S 22)$. [5]

b) Koncepci výstavby armády (zákon 219/1999 Sb., § 6, písm. d). [6]

c) Strategickou koncepci obrany státu (zákon 222/1999 Sb., § 5, písm. b). [4]

d) Koncepci mobilizace ozbrojených sil (zákon 222/1999 Sb., § 5, písm. f). [7]

e) Koncepci přípravy občanů k obraně státu (zákon 222/1999 Sb., § 5, písm. h). [8]

Mimo tyto explicitně jmenované koncepce, podle zákona 222/1999 Sb., § 6, písm. a), Ministerstvo obrany navrhuje vládě základní opatření $\mathbf{k}$ přípravě a organizování obrany státu, k čemuž zejména zpracovává obranné koncepce a požadavky na zabezpečení obrany státu. Zákon 222/1999 Sb. dále explicitně uvádí, že vláda schvaluje směry použití ozbrojených sil a směry přípravy ozbrojených sil. Např́klad jeden z posledních draftů Dlouhodobé vize rezortu obrany (2008) [9] obsahoval seznam rezortních dokumentů, které bude nutné zpracovat - ,záměry, koncepce a analýzy rozvoje“:

$\square$ řídících procesů a organizačních struktur,

$\square$ personálního řízení a přípravy příslušníků rezortu,

$\square$ ekonomického řízení a zabezpečení,

$\square$ systému akvizic,

$\checkmark$ infrastruktury a rozmístění posádek,

$\square$ logistické podpory,

$\square$ vojenských publikací a předpisů,

$\square$ výzkumu a vývoje,

$\square$ systému mobilizace,

$\square$ operační koncepce použití sil a prostředků.

Tento seznam se ale ve finálním dokumentu neobjevil.

Pokud se podíváme na současný stav zpracování a schválení výše uvedených strategických dokumentů, tak pouze Koncepce výstavby armády nebyla v posledních letech aktualizována a schválena vládou.

Samozřejmě ihned vyvstane otázka, kam do této struktury koncepčních strategických dokumentů patří Bezpečnostní strategie ČR, Obranná strategie ČR, Bílá kniha o obraně 
a Koncepce výstavby armády? Na tuto otázku lze najít odpověd' v Metodice př́ípravy veřejných strategií (2012). Pro pochopení současného stavu koncepční tvorby v rezortu obrany je ale nejdříve nutné se podívat na Metodiku střednědobých koncepcí (2001), podle které se koncepční tvorba řídila v posledních deseti letech.

\section{Metodika střednědobých koncepcí 2001 a tvorba koncepcí v rezortu obrany}

Metodika střednědobých koncepcí [1] říká, že střednědobé koncepce ministerstev jsou základním prvkem úvah o zaměření české ekonomiky a podkladem pro zpracování Střednědobé koncepce sociálního a ekonomického rozvoje. Otázkou je, jaký je vztah zákonem stanovených koncepcí zpracovávaných v působnosti rezortu obrany, včetně Koncepce výstavby armády, $\mathrm{k}$, úvahám o zaměření ekonomiky a sociálně ekonomickému rozvoji “ společnosti? Odpověd' je jednoznačně ANO, je ale nutné říci v čem. Především jde o stanovení potřeby prostředků ze státního rozpočtu na výstavbu ozbrojených sil, budování a udržování kapacit pro zajištění potřeb společnosti a ozbrojených sil za krizových stavů. Sociálně-ekonomický dopad se projevuje formou vytváření pracovních míst, investicemi, vytvářením spotřeby dislokovanými vojsky na regionální a komunální úrovni.

Metodika dále říká, že střednědobé koncepce umožňuji sladit krátkodobé záměry se střednědobými cíli", a tím dosahovat maximálních účinků využívání omezených zdrojů. V tomto konstatování je skryt strukturální problém stanovování cílů. Předpokládáme-li, že střednědobé koncepce obsahují střednědobé cíle, které jsou poté transformovány do krátkodobých záměrů, tak již jen použité pojmy jsou zavádějící. Pojem záměr je velmi obecný. Můžeme mít záměr, jak budou vypadat ozbrojené síly a z tohoto záměru poté lze generovat strategické cíle. Ze strategických cílů lze generovat záměr jak je dosáhnout a jakým zpơsobem využít dostupné zdroje. Proto je nutné hovořit o dlouhodobých záměrech neboli vizích a dlouhodobých (strategických) cílech. Čím ale jsou tyto stanoveny? Závažným problémem je i otázka využívání omezených zdrojů neboli specifikaci rozpočtových nákladů na výstavbu armády. Jestliže hovoříme o střednědobých cílech a dlouhodobém výhledu, tak hovoříme o horizontech pěti let, v případě některých vyzbrojovacích programů i deseti let. Dnes ale nejsme schopni přesněji vymezit rozpočtový výhled na více jak dva roky a predikci o rok déle. Podle vyjádření Ministerstva financí jsou jakékoliv delší predikce spíše fikcí.

Mohli bychom říci, že si pod pojmem „Strategická koncepce obrany státu“ představujeme Bezpečnostní strategii ČR a Obrannou strategii ČR. Tyto dva strategické dokumenty stanovují dlouhodobé cíle, ve výhledu více jak pět let. Dlouhodobé cíle by poté měly být rozpracovány v dalších strategických dokumentech definovaných zákony, včetně Koncepce výstavby armády. Protože jejich realizace vyžaduje období delší pěti let, tak nemůžeme v žádném případě hovořit pouze o stř̌ednědobých koncepcích.

Tento rozpor potvrzuje i další konstatování metodiky, že východiskem tvorby střednědobých koncepcí jsou priority vlády obsažené v jejím programovém prohlášení. Víme, že volební období je čtyřleté a každá vláda zpracovává své programové prohlášení na volební období. Tento princip neumožňuje stanovování dlouhodobých cílů (priorit). Programové prohlášení by nemělo být východiskem, ale rámcem pro strategie rozvoje svěřených odvětví. Rámec vymezuje realizaci strategie v daném období tím, že upřesňuje 
priority sociálně-ekonomického rozvoje společnosti. Dlouhodobé cíle v horizontu 15 let by měly zůstat pokud možno nezměněné. Proto je důležité, aby zákonem stanovené koncepční dokumenty byly schvalovány napříč politickým spektrem a byla zajištěna návaznost cílů i při změně sociálně-ekonomických priorit vlád.

Aby to bylo ještě více nesrozumitelné, metodika říká, že rámec střednědobých koncepcí tvoří „,vize rozvoje“, která se vypracovává na období 15 let a obsahuje základní trendy a jejich predpokládané di̊sledky v daném období. Otázkou poté je, zda strategické koncepce rozvoje svěřnéch odvětví a řešení stěžejních otázek (zákony stanovené koncepce) nemají být oněmi „vizemi rozvoje“? Jaký by pak ale k nim měla vztah koncepce Dlouhodobého výhledu rezortu Ministerstva obrany (2008)? V další části článku je představena úvaha o místu Dlouhodobého výhledu rezortu obrany v tvorbě strategických dokumentů a jejímu vztahu ke Koncepci výstavby armády.

Metodika dále stanovuje obsah střednědobé koncepce:

1. Stanovení cílů rozvoje včetně určení priorit, a to nejenom v poloze kvalitativní, ale tam, kde je to možné, i kvantitativní.

2. Identifikaci cílů, které vyžadují spolupráci více ministerstev a případně cílů, které jsou nekompatibilní s cíli koncepcí jiných ministerstev.

3. Specifikaci programů, které konkretizují realizaci koncepce v jednotlivých dílčích oblastech.

4. Kvantifikaci nároků na finanční zdroje.

5. Očekávané důsledky koncepcí a programů v jednotlivých letech, a to i v průřezových oblastech jako je oblast životního prostředí a oblast sociální (zaměstnanost), pokud je to možné i v kvantitativní podobě.

6. Regionální rozměr koncepce.

7. Legislativní a nelegislativní opatření, která koncepce vyžaduje.

Bez toho, že bychom se zamýšleli nad konkrétním obsahem jednotlivých bodů ve vztahu ke Koncepci výstavby armády, lze celkově říci, že podle této metodiky koncepce má obsahovat definované cíle - způsoby jejich dosažení (programy) - zdroje potřebné $\mathrm{k}$ jejich realizaci.

Tímto se ale dostáváme do zásadního rozporu s teorií a praxí strategického řízení. Například Grasseová a kol. uvádějí: „Strategie je způsob (cesta), kterým organizace realizuje své poslání a vizi. Je založena na potřebách hlavních zainteresovaných stran a podporována př́slušnými politikami (koncepcemi), plány, cíli, záměry a procesy. Zpravidla jde o prostředky, metody, procesy a zdroje vyžadované ... pro dosažení strategických cílů, včetně jejich př́padné změny. “ [10]

US Army War College Guide to National Security Issues (2008) definuje model strategie jako paradigma „cíli̊ - způsobů jejich dosažení - dostupných zdrojů“. [11] Je tedy zcela zřejmé, že vládní Metodika střednědobých koncepcí (2001) nepopisuje tvorbu koncepcí, ale popisuje tvorbu strategií. Každá strategie ale vychází z posloupnosti strategických dokumentů: politiky - vize - koncepce. [1]

Pokud bychom přistoupili na tuto filozofii, tak se nemůže tvorba zákonem stanovené Koncepce výstavby armády řídit Metodikou střednědobých koncepcí (2001).

Těmito rozpory byla poznamenána koncepční tvorba v rezortu obrany, Koncepce rozvoje AČR (2009), Dlouhodobá vize rezortu Ministerstva obrany (2008) a další koncepce zpracovávané v působnosti AČR. 


\section{Metodika přípravy veřejných strategií 2012 a tvorba Koncepce výstavby armády}

Projekt Metodika př́pravy veřejných strategií byl koordinován Ministerstvem financí České republiky pod gescí vlády České republiky za účelem vytvoření jednotného přístupu k tvorbě klíčových strategických materiálů v českém veřejném sektoru. [2] Projekt měl úzkou vazbu na projekt „Efektivní veřejná správa a přátelské veřejné služby - Strategie realizace Smart Administration v letech 2007-2015“. Projekt byl financován z Evropského sociálního fondu prostřednictvím Operačního programu Lidské zdroje a zaměstnanost. [12]

Přestože název nese ve svém obsahu přípravu strategií, tak se zabývá celou problematikou tvorby strategických dokumentů: vizí, koncepcí, strategií a programů (plánů). Velký přínos metodiky je v tom, že vymezuje používané pojmy, dává řád do tvorby strategických dokumentů a předkládá návrh metodologie jejich zpracování. I když se nejedná o nic zcela nového z pohledu teorie, tak přinejmenším v rámci státní správy vytváří jednotný rámec pro tvorbu strategických dokumentů a definičně vymezuje jejich jednotlivé typy.

\section{Posloupnost strategických dokumentů}

Pokud se podíváme na strukturu a obsah jednotlivých koncepcí zpracovávaných od roku 1993 v působnosti rezortu obrany, tak vždy vypracoval, nebo se snažil vypracovat strategie rozvoje. Tedy dokumenty, které by měly navazovat na vizi - politiku - koncepci. Bezpečnostní strategie ČR a Obranná (dř́ive vojenská) strategie ČR měly tendenci zahrnout politiku, vizi, koncepci a strategický rámec dohromady. Postup měl svoji logiku, ale byl špatně používán pojmový aparát, a tím docházelo k matení účelu, závaznosti a návaznosti jednotlivých dokumentů.

Od vzniku samostatné České republiky byla zpracována řada strategických dokumentů v oblasti bezpečnosti a obrany, viz tab. 1 . Z tohoto přehledu je zřejmé, že neexistuje časová souslednost, můžeme říci hierarchie zpracování strategických dokumentů, které by měly na sebe z pohledu řízení navazovat. Do této tabulky je zapracován názor autora na zařazení uvedených dokumentů podle jejich obsahu a pojmosloví Metodiky přípravy veřejných strategií 2012. V průběhu let nebyla dodržována struktura strategických dokumentů stanovujících ,vizi - politiku - koncepci - strategii - plán - program“. Jedná se o stav, který byl před několika lety kritizován PhDr. Raškem, [13] kdy Bezpečnostní strategie ČR představuje politické zadání, jehož teze mají být rozpracovány v navazujících koncepčních dokumentech. Konkrétnost tezí je však nedostatečná pro stanovení koncepčních předpokladů, [9] rozumějme koncepce, které by byly východiskem pro strategie a následně pro střednědobé plány. Podrobně se problematikou politiky a strategie zabývá studie autorů J. Ludvíka L. Moravce [14] ve vztahu k Bezpečnostní strategii ČR. I z této studie plyne, že stanovení cílů je věcí politiky, zatímco jejich realizace a využití zdrojů jsou záležitostí strategie. Podle autorů Bezpečnostní strategie 2003 obsahovala výčet cílů a hrozeb, ale bez jejich prioritizace. [15] Jednalo se tedy o ,politiku“, protože dokument neřešil způsoby jejich dosažení a využití dostupných zdrojů k jejich realizaci.

Pokud bychom vzali soubor všech definovaných strategických dokumentů dle Metodiky přípravy veřejných strategií, [2] názvy strategických dokumentů zpracovávaných 
Tab. 1: Výběr definic strategických dokumentů

\begin{tabular}{|c|c|}
\hline Pojem & Definice \\
\hline $\begin{array}{l}\text { Strategický } \\
\text { dokument }\end{array}$ & $\begin{array}{l}\text { Jakýkoliv dokument stanovující vizi, cíle nebo opatření ve stanovené } \\
\text { oblasti. Strategickým dokumentem může být strategie, koncepce, akční } \\
\text { plán, rozvojový plán apod. }\end{array}$ \\
\hline Vize & $\begin{array}{l}\text { Popis žádoucího budoucího stavu, kterého chceme prostřednictvím realizace } \\
\text { strategie dosáhnout. Jedná se o dopad naplnění globálního cíle. Vztahuje } \\
\text { se na strategii jako celek. K naplnění vize by mělo dojít ve střednědobém } \\
\text { či dlouhodobém horizontu (což nemusí být bezprostředně po ukončení realizace } \\
\text { strategie). }\end{array}$ \\
\hline Politika & $\begin{array}{l}\text { V kontextu př́ípravy veřejných strategií (respektive jako název strategického } \\
\text { dokumentu) se jedná o vrcholový strategický dokument stanovující vizi, } \\
\text { základní cíle a směry vývoje v dané oblasti / sektoru, a to ve střednědobém } \\
\text { až dlouhodobém horizontu. Politika dále může stanovit základní principy nebo } \\
\text { charakter naplňování stanovených cílů. } \\
\text { Na politiku navazují další strategické dokumenty (např. strategie, strategické } \\
\text { plány apod.), které její cíle upřesňují a stanovují opatření k jejich realizaci. }\end{array}$ \\
\hline Koncepce & $\begin{array}{l}\text { V kontextu strategického řízení označuje pojem koncepce strukturované } \\
\text { vytyčení celkového směřování v dané oblasti. Koncepce obsahuje základní } \\
\text { východiska a směrování, zatímco strategie je konkrétnější, vymezuje konkrétní } \\
\text { cíle a jejich hodnoty. } \\
\text { Koncepce může mít podobný charakter jako politika, rozdíl je především } \\
\text { v jejich časovém horizontu (koncepce má spíše krátkodobý až střednědobý } \\
\text { horizont realizace, zatímco politika střednědobý až dlouhodobý horizont } \\
\text { realizace). }\end{array}$ \\
\hline Strategický rámec & $\begin{array}{l}\text { Podobně jako politika nebo koncepce se jedná o vrcholový strategický } \\
\text { dokument stanovující základní strategické cíle v dané oblasti / sektoru. } \\
\text { Na rozdíl od politiky nedefinuje vizi (ta je už předem stanovena jiným } \\
\text { dokumentem). } \\
\text { Na strategický rámec navazují další strategické dokumenty (např. strategie, } \\
\text { strategické plány apod.), které jeho cíle upřesňují a stanovují opatření k jejich } \\
\text { realizaci. }\end{array}$ \\
\hline $\begin{array}{l}\text { Dlouhodobý } \\
\text { rozvojový záměr } \\
\text { (plán) }\end{array}$ & $\begin{array}{l}\text { Dokument stanovující základní směry a cíle dalšího vývoje dané oblasti, } \\
\text { přčemž zároveň definuje rámcová opatření určená k realizaci, a to v delším } \\
\text { časovém horizontu. } \\
\text { Na tento dokument následně mohou navazovat akční plány nebo programy, } \\
\text { které specifikují konkrétní opatření a aktivity určené k realizaci v kratším } \\
\text { časovém horizontu. }\end{array}$ \\
\hline (Veřejná) Strategie & $\begin{array}{l}\text { Strategie vypracovaná subjektem veřejné správy jako ucelený soubor } \\
\text { opatření směřujících k dosažení cílů v definované oblasti. }\end{array}$ \\
\hline Bílá kniha & $\begin{array}{l}\text { Bílá kniha je zpráva nebo př́ručka, která pomáhá řešit vybranou } \\
\text { problematiku a usnadňuje činit rozhodnutí. Bílé knihy obsahují konkrétní } \\
\text { návrhy pro přijetí opatření ve specifických oblastech politiky. Bílá kniha je } \\
\text { předkládána pro posouzení politické reprezentaci. }\end{array}$ \\
\hline
\end{tabular}

Zdroj: Metodika přípravy veřejných strategií, s. 99-101. [2]

v působnosti rezortu obrany a konkrétnost stanovovaných cílů a přijímaných opatření k jejich realizaci, tak bychom mohli dostat matici, kterou znázorňuje tab. 3 (str. 23).

Aby určení a vymezení obsahu strategických dokumentů v působnosti rezortu obrany bylo naplněno, je nutné, aby rezortní strategické dokumenty odpovídaly charakteru výše uvedených definic. V současné době tomu tak není a jednotlivé dokumenty, 
Tab. 2: Přehled zpracovaných strategických dokumentů ČR v oblasti bezpečnosti od roku 1993 a jejich zařazení do typů strategických dokumentů

\begin{tabular}{|c|c|c|}
\hline Rok & Název & Typ dokumentu \\
\hline 1995 & Bílá kniha o obraně ČR & bílá kniha \\
\hline 1997 & Národní obranná strategie ČR & politika \\
\hline 1997 & $\begin{array}{l}\text { Záměr koncepce výstavby AČR do roku } 2000 \text { s výhledem do roku } \\
2005\end{array}$ & strategie \\
\hline 1999 & Vojenská strategie ČR & politika \\
\hline 1999 & Bezpečnostní strategie ČR & politika \\
\hline 2001 & Bezpečnostní strategie ČR & politika \\
\hline 2001 & Doktrína Armády České republiky & politika \\
\hline 2002 & $\begin{array}{l}\text { Koncepce výstavby profesionální AČR a mobilizace ozbrojených sil } \\
\text { ČR }\end{array}$ & strategie \\
\hline 2002 & Vojenská strategie ČR & politika \\
\hline 2003 & Bezpečnostní strategie ČR & politika \\
\hline 2003 & $\begin{array}{l}\text { Koncepce výstavby profesionální AČR a mobilizace ozbrojených sil } \\
\text { ČR přepracovaná na změněný zdrojový rámec }\end{array}$ & strategie \\
\hline 2004 & Doktrína AČR & politika \\
\hline 2004 & Národní strategie vyzbrojování & strategický rámec \\
\hline 2004 & Vojenská strategie ČR & politika \\
\hline 2006 & Zpráva o zajištění obrany ČR & $\begin{array}{l}\text { implementační / } \\
\text { prováděcí dokument }\end{array}$ \\
\hline 2006 & Zpráva o bezpečnosti ČR & $\begin{array}{l}\text { implementační / } \\
\text { prováděcí dokument }\end{array}$ \\
\hline 2007 & Plán obrany ČR & plán implementace \\
\hline 2007 & Transformace resortu Ministerstva obrany České republiky & strategie \\
\hline 2008 & Dlouhodobá vize resortu MO & $\begin{array}{l}\text { dlouhodobý } \\
\text { rozvojový záměr }\end{array}$ \\
\hline 2008 & Principy obrany ČR 2030 & politika \\
\hline 2008 & Vojenská strategie ČR & politika \\
\hline 2009 & Obranná politika Československé a České republiky 1989-2009 & politika \\
\hline 2011 & Bezpečnostní strategie České republiky - září 2011 & politika \\
\hline 2012 & $\begin{array}{l}\text { Obranná strategie České republiky - září } 2012 \text { (nahrazuje Vojenskou } \\
\text { strategii ČR z roku 2008) }\end{array}$ & politika \\
\hline 2013 & Koncepce aktivní zálohy & strategie \\
\hline 2013 & Koncepce přípravy občanů k obraně státu & politika \\
\hline 2013 & Koncepce mobilizace & $\begin{array}{l}\text { politika / prováděcí } \\
\text { dokument }\end{array}$ \\
\hline
\end{tabular}

Zdroj: Vlastní.

počínaje Dlouhodobým výhledem rezortu Ministerstva obrany (2008), přes Bílou knihu o obraně (2011) a konče např́iklad Koncepcí rozvoje vrtulníkového letectva, se snaží být vizí, politikou, strategickým rámcem i strategií současně. Často obsahují i rámcové programové okruhy. Pokud bychom přistoupili na logiku prŕstupu a definice uvedené v Metodice př́ípravy veřejných strategií 2012, tak Koncepce výstavby armády je jedním 
Tab. 3: Návrh určení a vymezení obsahu strategických dokumentů v působnosti rezortu obrany

\begin{tabular}{|c|c|c|c|c|c|c|}
\hline $\begin{array}{l}\text { Název strategického } \\
\text { dokumentu }\end{array}$ & $\begin{array}{l}\text { Název strategického dokumentu } \\
\text { v působnosti MO }\end{array}$ & 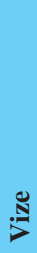 & 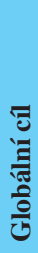 & 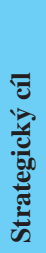 &  & है \\
\hline Vize & Dlouhodobá vize zajištění bezpečnosti ČR & & & & & \\
\hline Politika & $\begin{array}{l}\text { Bezpečnostní strategie ČR } \\
\text { Obranná strategie ČR }\end{array}$ & $\begin{array}{l}x \\
x\end{array}$ & $\begin{array}{l}x \\
x\end{array}$ & & & \\
\hline (Rezortní) Vize & $\begin{array}{l}\text { Dlouhodobá vize zajištění obrany } \\
\text { České republiky }\end{array}$ & & & & & \\
\hline Koncepce & $\begin{array}{l}\text { Strategická koncepce obrany státu } \\
\text { Koncepce mobilizace OS } \\
\text { Koncepce aktivních záloh OS ČR } \\
\text { Koncepce přípravy občanů k obraně státu } \\
\text { Koncepce operační přípravy národního území } \\
\text { Koncepce výstavby armády }\end{array}$ & & & $\begin{array}{l}\times \\
\times \\
\times \\
\times \\
x\end{array}$ & $\begin{array}{l}x \\
\times \\
\times \\
\times \\
\times \\
\times\end{array}$ & \\
\hline Strategický rámec & $\begin{array}{l}\text { Programové prohlášení vlády } \\
\text { Bílá kniha o obraně }\end{array}$ & $\begin{array}{r}x \\
\times\end{array}$ & $x$ & $x$ & & \\
\hline $\begin{array}{l}\text { Dlouhodobý } \\
\text { rozvojový rámec }\end{array}$ & Dlouhodobá vize rozvoje rezortu obrany & & & $x$ & & \\
\hline (Veřejná) Strategie & Strategie výstavby armády $202 X$ & & & $x$ & & $x$ \\
\hline \multicolumn{7}{|l|}{ Strategický plán } \\
\hline (Rezortní) Koncepce & $\begin{array}{l}\text { Koncepce výstavy druhů sil a druhů vojsk } \\
\text { Koncepce použití sil a druhů vojsk } \\
\text { Koncepce př́pravy } \\
\text { a další }\end{array}$ & & & & $x$ & $x$ \\
\hline $\begin{array}{l}\text { Implementační } \\
\text { dokument }\end{array}$ & Střednědobý plán rezortu obrany & & & & $x$ & $x$ \\
\hline Program & Programový okruh & & & & $x$ & $x$ \\
\hline Zásady & Směrnice ministra pro plánování & & & & & $x$ \\
\hline
\end{tabular}

Poznámka: Kurzivou jsou uvedené dokumenty, které podle autora ve struktuře strategických dokumentů chybí.

ze strategických dokumentů strukturovaně vyučujících celkové směřování v oblasti výstavby armády v dlouhodobém pohledu. Koncepce výstavby by měla obsahovat základní východiska a směřování výstavby AČR.

Koncepce výstavby armády by tedy neměla řešit otázky na konkrétní specifické cíle, způsoby jejich dosažení a vymezení zdrojového rámce. Toto je obsahem strategie výstavby. Takovýto dokument ale v rezortu obrany neexistuje a je snaha kompilovat jak koncepci, tak strategii výstavby armády v jednom dokumentu.

Metodika přípravy veřejných strategií navrhuje následující obsah strategie, ne vize, politiky, koncepce, nebo strategického rámce:

a) proč je daná strategie vytvářena,

b) co daná strategie řeší (jaký problém) a v jakém hodnotovém kontextu (tj. na základě jakých kritérií), 
c) jak bude daný problém řešen (a zda vůbec bude řešen),

d) jaký je cílový stav, kterého by mělo být realizací strategie dosaženo,

e) kdy se bude problém řešit a kdy bude vyřešen,

f) kdo bude problém řešit,

g) jak dlouho daná strategie platí,

h) kolik bude dané řešení stát (tj. jaké zdroje - finanční, lidské, organizační bude nutno na dané řešení vynaložit) a kdo poskytne potřebné zdroje. [2]

Rezort obrany respektive sekce obranné politiky a strategie Ministerstva obrany má v gesci správu Dlouhodobého výhledu rezortu obrany na 15 let dopředu. Otázkou je, zda má tento výhled představovat vizi nebo rámec v souladu s definicemi metodiky. Pokud by měl být vizí, tak by jeho místo mělo být nad bezpečnostní a obrannou strategií, protože by popisoval ideální stav bezpečnosti a obrany v budoucnu. Jeho název by poté měl být „Dlouhodobá vize zajištění bezpečnosti České republiky“. Pokud by měl být rámcem, tak by východisky pro jeho zpracování byly obě strategie a zákony stanovené koncepce, včetně Koncepce výstavby armády. Dlouhodobý výhled by slad'oval cíle strategií a koncepcí a způsoby jejich dosažení. Role dlouhodobého výhledu by poté byla koordinační a usměrňující ve vztahu ke střednědobému plánu. Z procesního pohledu by tedy bylo nutné nejdříve zpracovat Koncepci výstavby armády a až poté Dlouhodobý výhled (vize) rozvoje rezortu obrany.

Dlouhodobý výhled (zabezpečení obrany ČR) by mohl také představovat aplikační dokument, který by transformoval cíle uvedené v bezpečnostní a obranné strategii do cílů pro jednotlivé zákonem stanovené koncepční strategické dokumenty. Poté by ale bylo nutné, aby dlouhodobý výhled obsahoval strategické plánovací předpoklady a úkoly, jejichž plnění bude společnost očekávat ve výhledu 15 let a dále. Tyto úkoly jsou rámcově dány naším zapojením do kolektivní obrany a bezpečnosti v rámci NATO a Evropské unie, úkoly v rámci národního krizového systému a integrovaného záchranného systému a dalšími úkoly vyplývajícími ze zákonů České republiky, jako je například státní veterinární dozor v rámci rezortu obrany. Pokud by dlouhodobý výhled tyto vstupy pro strategickou koncepční tvorbu obsahoval, umožnilo by to provést poměrně přesné analytické vyhodnocení požadovaných vojenských schopností, potřeb a navržení způsobů dosažení cílů v daném sociálněekonomickém rámci. Pak by nejdříve byl zpracován strategický dokument Dlouhodobý výhled (vize) zajištění obrany ČR a následně koncepce, včetně Koncepce výstavby armády.

\section{Závěr}

V roce 2011 byla schválena nová Bezpečnostní strategie ČR, ve stejném roce vláda schválila Bílou knihu o obraně. Koncem září 2012 vláda schválila Obrannou strategii ČR. Tyto tři dokumenty představují politiku. Koncepce přípravy občanů k obraně státu byla schválena v roce 2102. Koncepce mobilizace ozbrojených sil a Koncepce aktivních záloh OS ČR byly schváleny v lednu 2013.

V současné době je stále platná Koncepce operační př́pravy národního území z roku 2004. Plán operační př́ípravy národního území na roky 2013 až 2016 byl schválen v lednu 2013. 
$\mathrm{Z}$ tohoto strohého výčtu je zrèejmé, že bude nutné aktualizovat Dlouhodobý výhled (vizi) zajištění obrany ČR jako strategický rámec pro zpracování zákonem stanovených koncepcí, nebo včetně Koncepce výstavby armády. Dále bude nutné zpracovat Dlouhodobý výhled (vizi) rozvoje rezortu obrany jako rámec pro střednědobé plánování. Je zcela zásadní rozlišit tyto dva strategické dokumenty, protože mají vymezen vztah ke Koncepci výstavby armády.

Jak konstatoval PhDr. Rašek, [13] teze obsažené v současných koncepcích bezpečnostní a obranné strategie by měly být rozpracovány do koncepčních předpokladů v Koncepci výstavby armády. Koncepční předpoklady by měly být východiskem pro zpracování Strategie výstavby armády. Již zmíněná Koncepce rozvoje Armády České republiky, která byla zpracována v roce 2009 , nebyla schválena. Střednědobé plány činnosti a rozvoje rezortu obrany tak vychází pouze strategických dokumentů stanovujících politiku a ze schválených koncepcí.

Jen stěží si lze představit zabezpečení obrany státu, pokud nevíme, jaká je koncepční představa budoucí Armády České republiky ve výhledu do roku 2025 a dále, jaká je koncepce jejich použití, nasazení, př́ípravy, vyzbrojování, dislokace, zajištění potřebných operačních zásob atd.

Vedle zákony explicitně jmenovaných strategických dokumentů by rezort obrany měl zpracovávat další rezortní strategické dokumenty nižšího řádu (vize, koncepce, strategie) rozvoje svěřených odvětví a řešení stěžejních otázek.

K tomu je ale nutné, aby se k již zpracovaným strategickým dokumentům přistupovalo terminologicky správně a aby závěry $\mathrm{v}$ nich uvedené byly interpretovaly podle toho, jaké poslání má dokument v hierarchii strategických dokumentů. I když je v současných dokumentech řešena otázka vizí, politik, strategických rámců i strategií současně, za podstatné a výchozí by se měla brát ta část, která odpovídá určení dokumentu.

Strategické dokumenty by neměly být připravovány jako slohová cvičení založená na kopírování konstatování zahraničních veřejně dostupných dokumentů. To, co je relevantní pro některého $\mathrm{z}$ aliančních partnerů, nemusí být bezpodmínečně relevantní pro Českou republiku. Každé konstatování, závěr nebo doporučení uvedené ve strategickém dokumentu by mělo být podloženo argumenty získanými analytickou prací. Univerzita Karlova v Praze, Fakulta sociálních věd, řeší v současné době projekt Grantové agentury České republiky na téma ,,analytici politiky v ústřední státní správě České republiky“. Už toto zadání projektu ukazuje, že máme problém s analytiky ve státní správě, kteří by podporovali rozhodování na strategické úrovni rízení. Dobrým analytikem se nestane úředník tím, že jej ustanovíme na funkci. Vedle osobních charakteristik a předpokladů takovýto úředník potřebuje specifické vzdělání a řadu let praxe, potřebuje znát odbornou problematiku, prostředí a podmínky její realizace.

Pokud jde o Koncepci výstavby armády, tak těmito odborníky by měli být důstojníci a občanští zaměstnanci, kteří mají dlouholeté zkušenosti z operačního použití AČR, z př́ípravy vojsk, jejich mírového zabezpečení, a také zkušenosti z působení v aliančních strukturách. Zlepšení lze očekávat. Pozitivní je projekt Ministerstva financí „Metodika př́ípravy veřejných strategiî“, a také např́íklad vytvoření Centra bezpečnostních a vojensko-strategických studií na Univerzitě obrany. Nelze ovšem očekávat, že Koncepci výstavby armády budou zpracovávat takováto pracoviště. Za př́ípravu této koncepce odpovídají vrcholoví funkcionáři rezortu obrany s př́íslušnou odpovědností a pravomocí. Analytici jim mohou poskytovat objektivní a zdůvodněné argumenty pro rozhodnutí. 


\section{Literatura a odkazy k textu:}

[1] Usnesení vlády České Republiky ze dne 3. ledna 2001 č. $10+P$ k návrhu Metodiky střednědobých koncepcí. 1. vyd. Praha: Úřad vlády, 2001. Dostupné z http://kormoran.vlada.cz/usneseni/usnweb. nsf/0/8C5D4F378A95123FC12571B60070C17C.

[2] Metodika př́pravy veřejných strategií [online]. Ministerstvo financí ČR. 1. vyd. Praha, 2012, 10. 5. 2013 [cit. 2013-05-12]. Dostupné z: http://www.verejne-strategie.cz/metodika.html.

[3] Zákon č. 2/1969 Sb., o zřízení ministerstev a jiných ústředních orgánů státní správy. Úplné znění na zákona, dostupné na http://www.epravo.cz/top/zakony/sbirka-zakonu/uplne-zneni-zakona-ze-dne8-ledna-1969-c-21969-sb-o-zrizeni-ministerstev-a-jinych-ustrednich-organu-statni-spravy-ceske-republiky-3142.html.

[4] Zákon č. 222/1999 Sb., o zajišt’ování obrany České republiky ze dne 14. září 1999, 31 str., bez ISBN, dostupný na http://www.mocr.army.cz/images/id_0000_1000/172/222m.pdf.

[5] Koncepce operační přípravy národního území. In zákon č. 2/1969 Sb., § 22, dostupné na http://www. zakonyprolidi.cz/cs/1969-2.

[6] Zákon č. 219/1999Sb., o ozbrojených silách České republiky. Dostupný na http://www.zakonyprolidi. $\mathrm{cz} / \mathrm{cs} / 1999-219$.

[7] Koncepce mobilizace ozbrojených sil. In zákon 222/1999 Sb., § 5, písm. f), dostupné na http://www. zakonyprolidi.cz/cs/1999-222; Koncepce mobilizace ozbrojených sil České republiky. Praha: MO ČR, 41 str. ISBN neuvedeno, dostupné na http://www.mocr.army.cz/scripts/file.php?id=140163\&down=yes $\%$ E2\%80\%8E.

[8] Koncepce přípravy občanů k obraně státu. In zákon 222/1999 Sb., § 5, písm. h), dostupné na http:// www.zakonyprolidi.cz/cs/1999-222.

[9] Dlouhodobá vize rezortu Ministerstva obrany. 1. vyd. Praha: Ministerstvo obrany, 2008,19 str. Dostupné na http://www.vlada.cz/assets/ppov/brs/dokumenty/dlouhodoba-vize-mo.pdf.

[10] GRASSEOVÁ, M. - DUBEC, R. - ŘEHÁK. D. Analýza v rukou manažera: 33 nejpoužívanějších metod strategického ř́zení. 1. vyd. Brno: Computer Press, 2010, 325 s. ISBN 978-80-251-2621-9.

[11] U. S. Army War College Guide to National Security Issue: Volume I: Theory of War and Strategy. 3rd Carlisle, Pensylvania: USAWC, 2008, ISBN 1-58487-356-6. Dostupné z http://www.strategicstudiesinstitute.army.mil/pdffiles/pub870.pdf.

[12] Informace o projektu, dostupné z http://www.verejne-strategie.cz/informace-o-projektu.html.

[13] RAŠEK, Antonín. NATO připravuje novou strategickou koncepci. Vojenské rozhledy, 2010, roč. 19 (51), č. 2, s. 3-21, ISSN 1210-3292.

[14] LUDVÍK, Jan - MORAVEC, Luděk. Co je strategie? Konceptualizace pojmu a model pro využití v Bezpečnostní strategii ČR. Working paper, 6/2011, Středisko bezpečnostní politiky, CESES, FSV, UK, SBP [online]. 2011 [cit. 2013-06-09]. Dostupné z http://sbp.fsv.cuni.cz/SBP-36-version1-TRS_ WP_06.pdf.

[15] Bezpečnostní strategie České republiky. Praha: Ministerstvo zahraničních věcí České republiky v edičním oddělení Ústavu mezinárodních vztahů, 2001, 16 s. ISBN 80-865-0606-1.

Hlavní silnou stránkou systému doplnění a mobilizace OS ČR je naplnění principu odložené potřeby a odložení nákladů na mobilizaci do budoucnosti, až tato potřeba nastane. Systém tak umožňuje minimalizovat čerpání značných finančních prostředků na mobilizační přípravy v míru (potřebné struktury, skladování a udržování zásob, příprava osob atd.) a převést jejich čerpání až do období, kdy skutečná potřeba nastane, ale s rizikem, že na obnovení této schopnosti budou náklady nepoměrně vyšší.

Slabou stránkou je, že systém je závislý na schopnosti státu včas identifikovat hrozbu, respektive narůstající riziko vojenského ohrožení, a včas se rozhodnout jaká nutná opatření přijmout, což je základním předpokladem a podmínkou úspěšného doplnění OS ČR. Zásadním nedostatkem je chybějící právní úprava celé škály nezbytných opatření, o kterých by bylo vládou rozhodnuto a která by byla realizována $\mathrm{v}$ míru $\mathrm{v}$ dostatečném předstihu před př́ípadným vyhlášením stavu ohrožení státu.

Koncepce mobilizace ozbrojených sil České republiky.

Praha: MO ČR, 2012, www.mocr.army.cz/scripts/file.php?id=140163\&down=yes. 